\title{
8
}

\section{Cook Islands Tivaivai and the Haircutting Ceremony in Auckland: Ritual Action, Money and the Parameters of Value}

\author{
Jane Horan
}

\section{Introduction}

The large cavernous Ātiu hall in Mangere-the community focus of the Cook Islands Ātiuan community in Auckland where most Cook Islanders live ${ }^{1}$ — was already packed with 500 people or more when I arrived late for the haircutting (pākoti'anga 'óora) of Māmā Lucy's nephew. I was shown to a seat at the front of the hall and felt the weight of the large crowd behind me. Everyone was seated at trestle tables facing towards the stage where the boy, who was no more than seven or eight, ${ }^{2}$ sat on a wide, deep

1 The island of Ātiu is one of 15 islands in the Cook Islands archipelago, but some 61,839 Cook Islanders live in New Zealand (Statistics New Zealand 2013), and less than 18,000 (Ministry of Finance and Economic Management 2017) reside in the island homelands. Of these, at least half live in Auckland. Cook Islanders in New Zealand 'make place' by the establishment of halls like the Âtiu Hall, and there is also a Pukapuka Hall, Manihiki Hall, as well as a Cook Islands Hall in South Auckland. These are all used extensively by the various island communities to stage ceremonial economy events.

2 The age of the boy having his hair ritually cut varies. Of the haircuttings I attended, three were for younger boys aged around seven or eight, which seems to be the average age, although I attended another haircutting that was for an older youth of 18. I heard about at least one other haircutting that was for a 21-year-old, which was combined with his 21 st birthday celebrations and was staged 
armchair with rolled arms, which had been covered by a finely stitched tivaivai taorei, an 'unquilted quilt' in the piecework style. ${ }^{3}$ Such textiles, made for the most part by women, are considered the most elite valuables in the Cook Islands ceremonial economy (Horan 2011, 2012, 2013). The haircutting is the Cook Islands male rite-of-passage ceremony that transitions a 'boy to man', ${ }^{4}$ and like other ceremonial economy events, such as weddings, funerals, public presentations to ministers and other dignitaries, tivaivai feature significantly and ostentatiously as the gift and/ or as decoration and adornment of people and ritual contexts.

The boy looked small and bewildered. His hair was braided into about 150 single locks each tied with a royal blue or a white ribbon, and it was these that were about to be ritually cut from his head as part of his haircutting. What these locks of hair were to be exchanged for, what constituted the other aspect of the rite of passage aside from the physical cutting of his hair, and defined the very specific form of adulthood that the boy was entering, were envelopes that boldly, explicitly bore the name of the giver-and contained a sum of money. The boy was about to be gifted money 'wrapped' in envelopes, but what he and his kin group were maintaining or acquiring were a set of obligations to reciprocate in kind as a form of connection. The focus on connection is countenanced,

as a large, prestigious event in the National Auditorium in Avarua in Rarotonga. Loomis (1983: 227) notes that for those who subscribe to the precontact origins of the rite, most assert that the 'traditional' age of the boy was generally older, over 20.

3 There are three main types of tivaivai: tivaivai taorei, which is made in the patchwork style; tivaivai tätaura, which feature several colours of appliquéd fabric with embroidery embellishment; and tivaivai manu, the simplest form, which consists of a pattern cut from one piece of fabric that is then appliquéd to a base fabric.

4 There is some debate about how traditional the haircutting ceremony actually is, but most agree that it is more common now than it used to be, especially in New Zealand (Ama 2003). Some of the people I spoke to about haircuttings said that it was a tradition that dated from the time before the missionaries came. However, others have scoffed at this and declared that it was a convention introduced by the missionaries. One woman told me 'it's a new thing'. Some think that the haircutting ceremony is just for title holders, others for the oldest son only of a nuclear family. Antony Hooper indicated that he neither saw nor was told about haircutting ceremonies amongst the Auckland Cook Islander population at the time of his research (late 1950s), and that it was his opinion that the current haircutting ceremony was essentially a copy of the Niuean event (personal correspondence cited in Loomis 1983: 230). In his own writing, Hooper asserts that it was the 21st celebration that was the key köpu tangata (extended kin) event of an individual's life (1961: 172) for both males and females. Now, because young women have never had a rite-of-passage celebration like the haircutting, 21st birthday celebrations are used to mark a more contemporary female transition, as are the presentation of tivaivai during an 'o' ora at the conclusion of a wedding ceremony. A wedding 'o ora used to done by the bride and her mother to present tivaivai and other household textiles to the new husband/son-in-law, but this is changing. Because fewer women make tivaivai now, the wedding 'o 'ora has evolved into a medium to pass on tivaivai to 'worthy' daughters, and to demonstrate the quality of the mother-daughter relationship (Horan 2012). 
for the most part, by nonagonistic gifting. But the staging of the ritual arena-including the strategic use of specific tivaivai made by his female relatives, and other textiles in what constitutes a hierarchy of textileswas especially efficacious and, I argue, integral to both the rite-of-passage process and the exchange of valuables because tivaivai effectively dignify the gifting of money in the service of Cook Islands kinship obligations and values.

The small boy sat wide-eyed on the chair, looking out over the assembled crowd of his extended family and invited guests, like me. From where I sat, the boy appeared at the centre of a profusion of textiles: propped either side of him, nestling him into the depths of the chair were cushions with blowsheet covers. ${ }^{5}$ Another tivaivai, in the manu style was draped around his legs. The stage area surrounds and the set of tables in front of the stage (for the honoured child, his friends and close family during the feasting part of the haircutting) were all festooned with blowsheets. The front face of the stage was also covered with blowsheets and propped along the edge of the stage, placed side by side, was a row of cushions with blowsheet covers edged with lace. On the floor, where the blowsheetcovered tables were placed, were plastic fibre mats, and in front of the children's main table was a chair draped with a tivaivai that was ready for the 'o' ora, a subsequent gifting event that was to come, where the boy was to be gifted tivaivai, as well as other textiles and household items. The overall effect of the ritual scene was of wrapped containment via a profusion of ranked textiles with the neophyte at the centre. It seemed to me that the small boy was effectively wrapped in concentric layers of cloth made by his female relatives. The layers of textiles radiated out from him: tivaivai, as the most elite textile, wrapped him at the centre; lesser textiles efficaciously wrapped the ritual arena and the honoured guests who sat in the front part of the hall.

5 Blowsheets are made by laying out plain cotton sheeting on the ground. Stencils of various motifs like flowers, leaves, birds, bunches of grapes, etc. are arrayed on the sheet in a decorative pattern. Then women take pots of paint, suck paint up into straws, and then literally blow it over the stencils. Several colours of paint are used, and the process done enough times so that once the stencils are removed, the pattern is revealed by the negative spaces. To make the most of the paint used, women also lay another cotton sheet over the paint covered stencils to imprint the stencil patterns to create a positive image on the other sheet. Blowsheets have the advantage of being quick and cheap to produce. On one particular day, I watched Māmā Lucy and other women from the Enuamanu Va'ine tini (tivaivai-making group) produce upwards of 100 blowsheets, some of these featured in the haircutting detailed in this chapter. 
This textile-adorned ritual context was to facilitate the transition the boy was making into a Cook Islanders' version of manhood. This public haircutting ritual was about conjoinment and the setting up for the boy of 'a particular future through exchange relationships' (Gershon 2007: 484) because a Cook Islands adult is one who is enmeshed in such a matrix of obligations. But as David Graeber (2001: 167) notes:

One cannot hope to understand circulation of valuables in a 'gift economy' ... without first taking into account more fundamental processes by which the human person is created and dissolved. And then when such general principles as action and reflection, or the movement between abstract potential and concrete form do appear-which they generally do- these too are always aspects of persons before they are aspects of things.

The making and use of a tivaivai as 'women's wealth' is really about 'how forms of value emerge to regulate a process which is ultimately about the creation of people' (Graeber 2001: 142). According to Terence Turner (2012: 501), values are what drive 'and constitute the most general purpose of social action and the most important qualities of personal identity'. For Cook Islanders, such values are about kinship and the performance of aro' $a$ (glossed as love, see below). These values dramatically inform the social activities and goals of most Cook Islanders in New Zealand, as well as elsewhere, to one degree or another, including the ritual action inherent in the haircutting ceremony, where, as with other ceremonial economy events, those values are materialised — literally and figurativelyby tivaivai.

This chapter is about the relationship between tivaivai made as a form of 'women's valuable' to be given as the gift and used as adornment of people and ceremonial venues, and the movement of money in the haircutting. I cast this relationship in the broader context of value (Turner 2006a, 2006b, 2008) as a structural component of the way Cook Islanders 'create their universe', to paraphrase Graeber (2013), and the way values are a refraction of value, while valuables are the materialisation of values. I argue that how and why tivaivai are in the very specific category of 'things that matter' (Miller 1998) is because they operate in ritual contexts as semiotic media of value (Turner 2008). The haircutting ceremony comprises an array of exchanges of material valuables that underscore the circulation of social values (Fajans 1993). In particular, the ritual complex 'fronted' by tivaivai is about highlighting, maintaining and creating new relationships for the neophyte as an emerging man and eventual husband and father, as well as signifying that the child is becoming a fully 
fledged adult member of his kin group. But it is also about the display of femaleness in the Cook Islands, and aro ' $^{\prime}$ and the performance of tivaivai in particular as valuables, as well as the public gifting of money wrapped in envelopes. However, the fact that the haircutting is being elaborated and ritual decoration with tivaivai in particular is intensifying, as the gifting of money is becoming more judicious is, I argue, in response to the broader capitalist context that Cook Islanders live in. The relationship among value, values and valuables is being ameliorated and elaborated for contemporary Cook Islanders such as Māmā Lucy, her nephew and their wider extended family. These layers are what this chapter is about.

\section{The ritual action at Māmā Lucy's nephew's haircutting}

As I took my designated seat towards the front of the hall for the haircutting, Māmā Vero, the most genealogically senior woman in the Auckland Ātiu community, had already begun to recite the boy's genealogy for all to hear. She stood in front of the crowd with a microphone in hand addressing the large audience. As the holder of the genealogies, Māmā Vero spoke as one who was used to commanding a room. An imposing woman, she was resplendent in a green-and-white päreu fabric ти'ити'u, her long white-grey hair was plaited in a single braid, and she wore a finely worked pandanus hat. Her attire adorned her as a woman of substance and mana (power, prestige). As she spoke, her skill as an orator was apparent. Her rapid Ātiuan was lost upon me but she used changes in tone, pauses and gestures to tell the story and command the attention of the crowd in a way that emanated mana. She had a direct, authoritative way about her that made everybody listen as she systematically linked virtually all of the people in the audience to the boy sitting on the stage: by birth, marriage and adoption, back through time to the islands and then to New Zealand. The timbre of her voice rose and fell as she told the history of the movement of kin backwards and forwards between the islands in the Cooks and beyond. The boy's place of birth, his 'enua'änau, was New Zealand, but his ipukarea, his homeland and ancestral home, was Ātiu and the other islands to which he and his family were connected. Everyone in the room was drawn together, all heard, the older ones remembered and the younger ones learned. Māmā Vero was mesmerising and it seemed to me that as she spoke, she literally talked the ritual into being (Keane 2001: 74). As she related the knowledge 
of where the little boy and the greater part of the audience belonged, this too was wrapped in the worked-upon array of textiles that adorned the hall and the boy. That wrapping with textiles and Māmā Vero's reciting of the genealogy set the ritual context for the exchanges that were about to happen, but also effectively 'circulated' values to do with the importance of kinship.

After the recitation of the genealogy, it was time to cut the locks of hair from the child's head. The Master of Ceremonies (MC) instructed the most senior people to file up onto the stage first. All the guests had been allocated a ranking number, which designated their order (Loomis 1983: 228; Ama 2003: 121). The most elite guests, followed by close family members, filed up first. Several of these initial people, who were probably closer family members, adorned the boy with neck garlands ('ei) made from artificial flowers, lollies, shells, ribbons and cash money notes. They would then cut their lock of hair from the child's head. There was at least one NZ\$100 note, multiple NZ\$20 and a number of NZ\$10 and NZ\$5 notes, totalling around NZ\$250. The boy was literally adorned and wrapped with various valuables-money and tivaivai.

After elite guests and close family, the remainder of the audience was sequentially invited to queue up in ranked order to take their turn on the stage and cut a lock of hair. Ushers worked from the front of the hall to the back, table by table, instructing the representatives of groups to line up. As these people filed up and took their turn on the stage to cut a lock of hair, I watched as each group handed an envelope that contained money to one or other of the parents who were attending their son. The envelope was tucked down beside the boy, and then the giver was handed a beribboned pair of scissors by one of the boy's parents and instructed by the other to cut a given lock of hair. Eventually, people at the section of tables where I was seated were ushered into the queue. As I filed up onto the stage and looked out over the large crowd, I was confronted by the noise and the expanse of people, and I wondered at the child's strained composure in the face of such public display. The three women in front of me were from a family of large Cook Islands women; they were wearing beautiful fragrant 'ei katu (head garlands) and their thick long black hair flowed down their backs. Two of these women were holding store-bought duvets in plastic packaging, which they intended to gift-in full view of the crowd - before cutting their lock of hair, thereby gaining maximum prestige (Loomis 1983: 220). They handed the textiles to Māmā Lucy, who was helping out on stage. The third woman had an 
envelope in her hand, which I noticed had her family's name on it; she handed this to the boy's mother and then cut her lock of hair. According to one of my informants, the giving of envelope-wrapped money and a gift, often a textile like a duvet, if not a tivaivai, is up to the individual. She said kin closest to the child usually give both, commensurate with their greater love for the boy and to signal their willingness to be a continuing part of his life in the future. She noted that 'sometimes you give money and sometimes you give money and a gift, it depends on your connection' (personal communication, Eva William, Auckland, 2011). But the money is always given in an envelope, so the name of the giver can be emblazoned on the front.

As I took my turn to cut the child's hair, I handed my envelope to the boy's mother; she placed the envelope in beside her son amid the growing pile of named envelopes. The boy's father handed me the scissors and instructed me where to cut a lock of hair between the ribbon and the boy's scalp. The child was still as my scissors bit into his hair, severing another lock from his head. I looked down at him, swaddled as he was in the profusion of textiles, and I was struck by the very public and drawnout nature of the process; the drama of the ritual as each piece of hair was seemingly exchanged for envelope-wrapped money. I took my lock of hair and walked to the other side of the stage. I passed Māmā Lucy, who smiled at me as she ordered the growing pile of duvets and other textiles and gifts that were amassing at the side of the stage. I returned to my seat and watched the rest of the crowd file up, give their envelopes and cut off their lock of hair. As the ritual cutting of the hair proceeded, the music troupe behind the boy on the stage played popular Cook Islands songs. There was lots of noise as people chatted and laughed and the atmosphere was festive. Some of the older women danced to the music as they stood in line, waiting to cut their lock of hair. The process took about 45 minutes because of the large number of people.

When all the braided locks had been cut from the little boy's head, a relative who was adept at actually trimming hair gave the boy his first haircut and styled the unevenly cut hair in front of the crowd. Māmā Lucy and his parents then took the young boy to the back area behind the stage, out of view of the crowd. The boy and his parents effectively transitioned through an 'off stage' (Goffman 1959) moment, to emerge transformed. His brief disappearance was important because the transition he was making was punctuated with a full change for him and his parents into clothing of the same fabric. When all three emerged from the back 
stage area, the boy and his father now wore green-and-yellow hibiscus päreu fabric shirts and dark trousers, and his mother had changed into a dress in the same fabric. The boy wore the money ' $e i$ around his neck and he wore a plaited pandanus hat with a garland of flowers on it over his newly cut hair. The change of clothing, of new textile wrappings in other words, heralded and underlined the transformation the boy had just made, as his hair was cut and he was gifted with what amounted to a sum in the vicinity of NZ\$6,000-\$8,000 as an education fund for his future.

The boy's parents lead him out into the hall area to loud and enthusiastic cheers from the crowd. As he came to stand in front of all the people, flanked by his parents, the young boy hung his head. He was trembling a little; he must have been finally overwhelmed by the crowd, the noise and the attention because he had started to cry. His mother coaxed and comforted him as he was paraded around the hall. Eventually, he was seated on the tivaivai-adorned chair that was placed in front of the head table at the front of the stage ready for the subsequent ' $o$ 'ora, and eventually the feast. He was rapidly becoming a very specific type of man.

\section{Tivaivai, value and values}

The ritual action of a haircutting ceremony, like that of Māmā Lucy's nephew's, is effectively a performance of Cook Islands values, via the use of valuables in exchange and adornment, prescribed by the structural parameters of value as perceived by Cook Islanders. Such core values for Cook Islanders are orientated to varying degrees by two multifaceted concepts: kinship and aro'a. Contained in the very definitions of these concepts are the means and methods for how people as Cook Islanders are connected to one another, as well as how to actually act appropriately and exist in the world. These concepts also define what is considered right generally and, more specifically, how Cook Islanders honour one another publicly. To use Turner's (2006b: 1) terminology, kinship is 'the main locus of the value relation and serve[s] as the source of the principal forms of social value', whereby the main modus operandi is aro' $a$. Herein lies the mode of belonging, of acting appropriately, of accessing prestige as mana, and garnering power and gain, which all require traffic in value, the adherence to values and the wielding of valuables. 
The Cook Islands kinship system links people to the land and to one another through membership via belonging, configured through cognatically reckoned extended family groups (Rasmussen 1995; Crocombe 1964). For Cook Islanders in New Zealand in particular, kinship links 'do not exist a priori' (Loomis 1983: 223). They need to be actualised via social interactions-for the most part via the public realm of the Cook Islands ceremonial economy-whereby all kin relationships are effectively a social construct that is either reproduced or neglected on a daily basis and 'dramatized in ritual' (1983: 223) in contexts like Māmā Lucy's nephew's haircutting ceremony. Connections forged via the gifting and use of tivaivai and other valuables 'define the person as a composite of relationships and features shared with others' (Gudeman 2008: 29). During kinship events, ceremonial processes turn the 'vast array of potential social relationships encoded in a person's or persons' kinship relationships into actual linkages traced and traceable ... by the flow of material wealth' (Evans 2001: 134). Those kinship linkages are maintained, underlined or manifested by the act of exchange because people 'do' kinship by the performance of aro 'a. However, ultimately, they are actualised by the circulation of value and the performance of values that are created by the ritual, and materialised by the use of tivaivai in particular.

The word aro' $a$ is an extremely complex term. The word is glossed as love but, linguistically, the notion of loving and showing love is contiguous with gifting as well as modes of decorum. From the dictionary, the word aro'a means:

1. greet, welcome, salute, offer good wishes to (especially to guests on arrival or departure)

2. to welcome with a gift, to present somebody with something (including publicly)

3. to forgive, have pity on

4. kindness, sympathy, sorrow, love as in divine love or loving kindness (Buse and Taringa 1995: 76).

Expressing aro' $a$ is about actions rather than just words. To gift is to show aro' $a$, to be loving towards a child is to show aro' $a$, to extend hospitality to kin or others is to show aro'a. To wrap a child at his haircutting ceremony in tivaivai demonstrates the quality of aro' $a$ in which he is held by his mother and/or his female relatives and wider kin group: it shows how much he is loved and to whom he belongs, and how he is cherished. To gift 
money to the neophyte is to acknowledge, support and express the desire to be connected to the individual and their kin group on display-but this is signalled as much by the amount of money in the envelope as by the name of the person/family group on the outside. These processes are all dignified by tivaivai as valuables, because the textiles in turn are ultimately the materialisation of values and the refraction of the structural parameters of value.

Aro' $a$ is expressed and shown by gifting, but the obligation created by such action is what conjoins people in the Maussian sense (Mauss 1990: 5; Alexeyeff 2004: 70). In Kalissa Alexeyeff's (2004) analysis of the gifting of food done by the woman with whom she lived in the Cook Islands, she noted that the woman gifted to her relatives to:

demonstrate her attachment to them and to incur obligation. This system of exchange was a central element of her understanding of relationships; goods and services are obtained primarily through gift exchange with relations and friends not by direct monetary payment. In this system, money could be given as a present, but it could not be given as a direct payment (2004: 74).

Alexeyeff was really writing about how Cook Islanders are conjoined. Her paper on food exchanges (2004) describes the food-giving part of a much bigger system of exchanges that interfaces with all aspects of Cook Islanders' lives; namely, the ceremonial economy that operates according to Cook Islands values via the exchange of valuables in an expanded notion of economy. Here, food is one of a number of valuables exchanged in this system; cash money and envelope-wrapped money are others, as are lesser textiles, the performance of dancing and locks of hair. However, overall, the most elite valuable is tivaivai. These effectively dignify the whole system because tivaivai are the valuables that express the most profound and closest of bonds in the domestic sphere. This mode is writ large in the public sphere (Graeber 2001: 73; 2013; Turner 2006b: 20) by the performance of the use and/or gifting of tivaivai in an ostentatiously public way, along with the public gifting of envelope-wrapped money.

Tivaivai and money-in specific ways-are objects that are turned into signs of invisible values. As a semiotic media of value, tivaivai are indexical symbols of the material activity that they mediate (Turner 2008); in doing so, tivaivai become seemingly able to dignify the gifting of money as an expression of aro'a. But, in effect, tivaivai are fetishised as the source of value because they materialise values as per the broader 
structural parameters of value. The combination of the textile decorations, the rhetoric of the genealogy, and the whole orchestrated ritual process that created a 'high formality of exchange', helped to:

separate signification and utility, emphasising the semiotic character of objects that also bear use and market value ... [whereby] such formality is part of the ongoing work effort it takes to keep gift and commodity distinct (Keane 2001: 73-74).

This formality was able to bring about the distinction between mere money and envelope-wrapped money because it referenced the specific parameters of value. The oratory, and the assiduous attention to the selection of specific textiles in wrapping and decoration, did 'work' in Webb Keane's sense. However, more fundamentally, they were about the circulation of value, the signalling of values, the materialisation of these as valuables and the evoking of the hierarchy of valuables.

Alfred Gell (1998) generally and Susanne Küchler (Küchler and Eimke 2009) specifically attribute agency to indexical qualities of the object and tivaivai respectively, in effect fetishising the source of value and agency. Whereas Turner (2006b, 2008) construes agency as emanating from the dynamic among value, values and valuables, which are the structural parameters of value within a given cultural group. Value is expressed as values, which are materialised in specific ways as valuables. Here, ideas of agency, the performance of actions and social consciousness are integrated with social organisation (Turner 2008: 43). This is what is happening when a child is wrapped in tivaivai at his haircutting ceremony.

\section{Tivaivai as valuables and the materialisation of values}

Tivaivai are a legacy of sorts of the colonisation of the Cook Islands, which began in 1821 with the arrival of the missionaries. Before tivaivai became the cloth of ceremony and prestige in the Cook Islands, woven mats and tapa cloth were used for ritual. These, made for the most part by women, had the power to sanctify by the process of physically wrapping (Kaeppler 2007; Sissons 2007). The arrival of the missionaries was the beginning of a process that changed the social nexus and, by the late 1800 s, tivaivai were being valued, and were more than likely beginning to eclipse indigenous textiles, as the cloth of ceremony and ritual (Herda 2010, 2011). Effectively, the process of the missionary conversion 
of Cook Islanders was mirrored in the conversion of their textile system from that made from locally grown fibres into the cloth fabric of tivaivai (Thomas 2000: 211). But how this happened, I argue, was derived from changes taking place in the parameters of value and values, which, in turn, changed what were considered 'valuables'.

The changing social nexus, including the emergence of tivaivai, was powered by dual processes: a local response to the regional changes that were sweeping eastern Polynesia through the 1800 s and early 1900 s (Sissons 2007, 2008), and internal power machinations coupled with the manifestation of missionary agendas in the Cook Islands. These included a particular version of the accompanying cult of domesticity where the teaching of sewing was an important missionary-led process, because sewing was seen as a way to control hands and bodies (Eves 1996; Weber 2009). Hence, missionary zeal and evangelism were not confined to the saving of souls (Colchester 2003; Comaroff and Comaroff 1992; Douglas 1999; Eves 1996; Jolly and Macintyre 1989). Rather, the conversion process was concerned with 'bringing the wider pattern of social life into some sort of conformity with English Christian ideas of marriage and familial life' (Thomas 2000: 211). The social habits that ordered work, how people lived and with whom, gender roles along with clothing, cloth and the interiors of houses were converted as well (203). What was ultimately changing was the social nexus (Küchler and Eimke 2009; Sissions 2007), but what those changes were amounted to changes in the general parameters of value, and specifically to changes in the way kinship and aro' $a^{\prime}$ as values were enacted and materialised as valuables. The subsequent inclusion of money in ceremonial gifting in a way that is subsumed below this performance of values in contemporary ceremonial contexts like Māmā Lucy's nephew's haircutting is a continuation and elaboration of this changing social nexus.

Tivaivai and matching pillowcases were initially made as decorations for the bed, which was the main piece of furniture in the home. As tivaivai have come to be fetishised as the paramount form of wealth in the Cook Islands ceremonial economy, they are concomitantly models of and models for femaleness, progeniture and kinship. Throughout the course of my research, time and time again, Cook Islands women told me 'you are not a woman without tivaivai. What 'woman' means here has three facets to it: women as females, women as mothers (and/or grandmothers, and/ or aunties) and women as Cook Islanders. The making and/or gifting of tivaivai is considered the ultimate expression of femaleness, of being a woman as an individual but also as part of how to publicly (for the 
most part) do relationships (Weiner 1976: 8). Women gift tivaivai to maintain, underline or create, as well as display, key relationships in their lives - of a son or nephew at his haircutting ceremony for example. But, in doing so, the making and/or use as decoration as well as the gifting of tivaivai effectively delineates a Cook Islands woman's essential muliebrity. At the same time, the use of tivaivai affects the wider assembled kin network at an event like a haircutting, whilst publicly defining who the emerging man is as an individual and as a member of a kin group. Tivaivai, as semiotic media of value, work on multiple levels, but always as refractions and materialisations of values and the broader structural parameters of value.

For older Cook Islands women, femaleness and womanliness have to do with mothering in particular ways: giving birth to and/or adopting children and raising them; dressing, behaving, carrying themselves in ways that show decorum and poise; being home makers and keeping house in a way that involves having tivaivai, in particular, with which to adorn their homes; and having the ability to sew tivaivai and being seen to do so. All of this has a public aspect to it which is very important. This muliebrity is performed when a woman gifts and/or uses her tivaivai as decoration and to adorn specific individuals at public ceremonial events. Most older women embody this ideology, and younger women, particularly those born and bred in the diaspora, have a different, ameliorated or abridged version. But regardless of the age of a woman or where she lives, who a woman is as a Cook Islander and mother, grandmother, auntie, extended kin, wife, is publicly displayed and broadcast when she gifts and/or uses tivaivai. In the process, for women as individuals or as groups of Cook Islands women, culturally sanctioned parameters of prestige as mana are created, because the making and/or use of tivaivai is the axis of and access to prestige. What is also circulated when tivaivai are used to adorn and wrap people and venues is a sense of what is symbolically essential about being a Cook Islander. The way tivaivai manifests, performs and signifies womanliness and mothering as the most important valuable interfaces with and underlines core values of the importance of kinship and the notion of aro' $a$ as a mode of action for Cook Islanders.

Rites of passage like the haircutting event are inevitably moments of teaching, when the society seeks to make the individual most fully its own, weaving group values and understandings into the private psyche so that internally provided individual motivations replaces external controls' (Myerhoff 1982: 112). This was the case for the initiate as Māmā Vero 
rousingly recited his genealogy, but a comparable process was happening for the audience too. They were reminded to whom, how and where they belonged, whereby part of the "ideological and dramaturgical "work" of the haircutting' (Loomis 1983: 230) is to galvanise and rouse kin to actively belong to the koppi tangata (extended family). This, in turn, provides the appropriate ritual context to facilitate the gifting of money, which has become the most pragmatic way of being actively family, and showing and doing aro' $a$. Both these have added impetus in the diasporic context.

To have the boy sitting on a tivaivai taorei with a tivaivai manu draped over his knees was to publicly signal how cherished he was in his family. He was allotted other tivaivai in the 'o ora that followed the haircutting process, but such specific use of tivaivai in the haircutting ritual to wrap the boy evoked specific values and made him appear motheredsmothered even in the materialisation of Cook Islands femaleness and mothering. As he sat on the stage flanked by his parents and other relatives, including his auntie, Māmā Lucy, the tivaivai were a sign of the purported integrity and strength of the family. In the display on the stage, the values of the domestic sphere and the aro' $a$ that ideologically operates there were being writ large, so to speak, in the public domain of the haircutting event (Turner 2006b: 12 and 20; Graeber 2001: 73) because of the use of tivaivai and other lower ranked textiles. The performance of the quality of kinship displayed in effect countenanced the motivation to gift envelope-wrapped money by the assembled group of extended kin. The wrapping and enthroning of the boy in elite textiles and the ritual stage area in lesser textiles accentuated the hierarchy of textiles that has such salience for Cook Islanders.

The symbolic change of clothing of both the boy and his parents was part of this dramaturgy, and showed that the boy was now connected to his parents and the kin networks they represented in a different way, and vice versa, as facilitated by the gifting of envelope-wrapped cash by the assembled extended kin. But the provision of good food, entertainment (generally Cook Islands dancing), the elaborately wrapped ceremonial venue and the judicious use of tivaivai in particular were essential parts of this because of the circulation of value (Fajans 1993) that they created and the exchange of valuables they ultimately contextualised. The ritual process facilitated the transition of the boy into a Cook Islands man and situated the gifts of money in what Stephen Gudeman (2008) calls the realm of mutuality vis-à-vis the realm of market. 


\section{Tivaivai and money}

When people choose to attend an event like Māmā Lucy's nephew's haircutting ceremony, and gift money in exchange for a lock of hair, they do so for a number of reasons: from being a way to help kin and actually do and show aro'a, or as a reciprocal gesture that answers a prior contribution from the family of the boy, or a desire to establish a link with a family or exert influence (Loomis 1983: 229). Regardless of the prime motivation, the gifts of textiles, money, food and services 'constitute kaio 'u "indebtedness"' (229). The recording of who gives what is done assiduously. After a haircutting, such a record constitutes a reference for the boy's interactions with his community of kindred in later life when he has become a man and is making his own way (229). One of my informants told me that there is always a book where who gives what and how much is noted in exacting detail at each event. She said, 'I always know what everyone gives' (personal communication, Eva William, Auckland, 2011), and it is important to know, because therein lies the relationship. Therein lies the ability to receive and eventually reciprocate. Therein lies the adherence to Cook Islands values and value via the movement of valuables. Terrence Loomis asserts that metaphorically, 'The strands of hair from the boy signify the reciprocal exchanges which bind participants together economically, symbolically and by kinship piri'anga [custom]' (1983: 229). But this only works because the locks of hair and money are ranked as valuables in a broader structure of value.

Cook Islanders in New Zealand have been and remain marginalised (Loomis 1985, 1990), featuring too regularly in the worst statistics from unemployment rates to levels of education (Statistics New Zealand 2013). But I argue that the Cook Islands ceremonial economy, in particular the haircutting ceremony, has evolved to give a more or less explicit acknowledgement of the economic realities in which Cook Islanders live. Cook Islanders have a specific understanding of money as it moves in the ceremonial economy, which is inevitably articulated with and is a function of the value of money in the market economy in which they live in New Zealand, but the two are not synonymous. They are related and managed, but are ritually managed to be explicitly different. Cook Islanders have articulated the capitalist economy with a fully fledged active ceremonial economy, which accommodates money in its midst as an important but nonsterile valuable that services social relationships in the way a good gift should, creating the requisite obligations and binding people together. 
People get by and do economy in a wider, more encompassing way that involves the realm of mutuality as well as market (Gudeman 2001, 2008). Nobody gets rich from participating in the Cook Islands ceremonial economy, but the system nonetheless operates to deliver sums of cash and quantities of food and support at key events in people's lives, and delivers cogent, powerful displays of values and modes of connection to all the participants in the ceremonies that mark those events.

Māmā Lucy's nephew was born in New Zealand, he is being raised and educated there, most of his extended family live there, and while he has the option of going back to the islands to live partly because he will have claims on land, he will more than likely end up living in New Zealand like two-thirds of the population of the Cook Islands. He has to function in a capitalist western economy. But the process of becoming a man to do this, from his Cook Islands family's point of view, was to be wrapped physically and metaphorically in textiles that trumpeted certain specific values about being a Cook Islander in New Zealand and about being a human being, and about ongoing relationships of belonging to his wider kin group. His hair was cut in exchange for sums of money, he was adorned with neck garlands that were embellished with cash money notes, and his passage to manhood was completed by a change of clothes, a feast and an 'o'ora where he was literally wrapped and adorned in more textiles, including tivaivai. What Māmā Lucy's nephew gained as his hair was cut was at least a nod to economic power, a network of kin to whom he is now obligated and conjoined, and he is now a Cook Islands man. The making and use of tivaivai as valuables is about how forms of value emerge to regulate a process which is ultimately about the creation of people' (Graeber 2001: 142).

\section{Acknowledgements}

I would like to thank Māmā Eva William and Māmā Lucy Papa for their help with this chapter. I am also grateful for the postdoctoral scholarship awarded to me by the Kate Edgar Educational Trust, which provided financial support while I researched and wrote about this topic. 


\section{References}

Alexeyeff, Kalissa. 2004. 'Love Food: Exchange and Sustenance in the Cook Islands Diaspora'. The Australian Journal of Anthropology 15(1): 68-79. DOI: $10.1111 /$ j.1835-9310.2004.tb00366.x.

Ama, 'Aka'iti. 2003. 'Maeva: Rites of Passage: Highlights of Family Life'. In Akon'anga Maori: Cook Islands Culture, ed. Ron Crocombe and Majorie Tua inekore Crocombe, pp. 119-125. Suva: Institute of Pacific Studies and Cook Islands Extension Centre, University of the South Pacific in association with the Cook Islands Cultural and Historic Places Trust and the Ministry of Cultural Development.

Buse, Jasper with Raututi Taringa. 1995. Cook Islands Maori Dictionary, ed. Bruce Biggs and Rangi Moeka'a. The Ministry of Education, Government of the Cook Islands; The School of Oriental and African Studies, the University of London; The Institute of Pacific Studies, The University of Auckland; Pacific Linguistics, The Research School of Pacific and Asian Studies, The Australian National University.

Carrier, James (ed.). 2005. The Handbook of Economic Anthropology. Cheltenham: Edward Elgar.

Colchester, Chloë (ed.). 2003. Clothing the Pacific. Oxford and New York: Berg Publishers.

Comaroff, Jean and John Comaroff. 1992. Of Revelation and Revolution: Christianity, Colonialism and Consciousness in South Africa. Chicago: Chicago University Press.

Crocombe, Ron. 1964. Land Tenure in the Cook Islands. Melbourne: Oxford University Press.

Crocombe, Ron and Majorie Tua inekore Crocombe (eds). 2003. Akon'anga Maori: Cook Islands Culture. Suva: Institute of Pacific Studies and Cook Islands Extension Centre, University of the South Pacific in association with the Cook Islands Cultural and Historic Places Trust and the Ministry of Cultural Development.

Douglas, Bronwen. 1999. 'Provocative Readings in Intransigent Archives: Finding Aneityumese Women'. Oceania 70(2): 111-129. DOI: 10.1002/j.1834-4461.1999.tb02996.x. 
Evans, Mike. 2001. Persistence of the Gift: Tongan Tradition in Transnational Context. Waterloo: Wilfrid Laurier University Press.

Eves, Richard. 1996. 'Colonialism, Corporeality, and Character: Methodist Missions and the Refashioning of Bodies in the Pacific'. History and Anthropology10(1):85-138.DOI: 10.1080/02757206.1996.9960893.

Fajans, Jane (ed.). 1993. Exchanging Products: Producing Exchange. Oceania Monographs. Sydney: University of Sydney.

Gell, Alfred. 1998. Art and Agency: An Anthropological Theory. Oxford: Clarendon Press.

Gershon, Ilana. 2007. 'Viewing Diasporas from the Pacific: What Pacific Ethnographies Offer Pacific Diaspora Studies'. The Contemporary Pacific 19(2): 474-502.

Goffman, Erving. 1959. The Presentation of Self in Everyday Life. New York: Anchor Books.

Graeber, David. 2001. Toward an Anthropological Theory of Value: The False Coin of Our Own Dreams. New York: Palgrave.

- 2005. 'Value: Anthropological Theories of Value'. In The Handbook of Economic Anthropology, ed. James Carrier, pp. 439-454. Cheltenham: Edward Elgar.

- 2013. 'It is Value that Brings Universes into Being'. Hau: Journal of Ethnographic Theory 3(2): 219-243. DOI: 10.14318/hau3.2.012.

Gudeman, Stephen. 2001. The Anthropology of Economy: Community, Market and Culture. Malden: Blackwell Publishing.

- 2008. Economy's Tension: The Dialectics of Community and Market. New York: Berghahn Books.

Hann, Chris and Keith Hart (eds). 2009. Market and Society: The Great Transformation Today. Cambridge: Cambridge University Press.

Herda, Phyllis. 2010. 'The Creation of a New Tradition: Women's Quilting in the Cook Islands'. Conference paper given at the Pacific Arts Association 10th International Symposium, Rarotonga, 9-11 August.

— 2011. 'Tivaevae: Women's Quilting in the Cook Islands'. Uncoverings 32: 55-78. 
Hooper, Antony. 1961. 'Cook Islanders in Auckland'. Journal of the Polynesian Society 70(2): 147-193.

Horan, Jane. 2011. 'Tivaivai and Value in the Cook Islands Ritual Economy: The Creation of Value, Values, and Valuables in a Diasporic Community'. In Textile Economies: Power and Value from the Local to the Transnational, ed. Walter E. Little and Patricia A. McAnany, pp. 57-76. New York: Altamira Press.

—_. 2012. 'Tivaivai in the Cook Islands Ceremonial Economy: An Analysis of Value'. PhD thesis. University of Auckland.

__. 2013. 'Tivaivai and the Managing of "Community" Funding in Auckland, New Zealand.' In Engaging with Capitalism: Cases from Oceania, Research in Economic Anthropology, Research in Economic Anthropology Volume 33, ed. Fiona McCormack and Kate Barclay, pp. 83-106. Bingley: Emerald Group Publishing Ltd.

Jolly, Margaret and Martha Macintyre (eds). 1989. Family and Gender in the Pacific. Cambridge: Cambridge University Press.

Kaeppler, Adrienne. 2007. 'Containers of Divinity'. Journal of the Polynesian Society 116(2): 97-130.

Keane, Webb. 2001. 'Money is No Object: Materiality, Desire, and Modernity in an Indonesian Society'. In The Empire of Things: Regimes of Value and Material Culture, ed. Fred R. Myers, pp. 65-90. Santa Fe, NM: School of American Research Press.

Küchler, Susanne and Andrea Eimke. 2009. Tivaivai: The Social Fabric of the Cook Islands. London: British Museum Press.

Little, Walter E. and Patricia A. McAnany (eds). 2011. Textile Economies: Power and Value from the Local to the Transnational. New York: Altamira Press.

Loomis, Terrence. 1983. 'The Cook Islands Haircutting Ritual as Practised in New Zealand'. Journal of the Polynesian Society 92(2): 215-232.

- 1985 . Samson in the South Pacific: Changes in the Symbolism of Hair in Polynesian-European Relations. Occasional Paper No. 5. Auckland: The Social Research and Development Trust. 
- 1990. Pacific Migrant Labour, Class and Racism in New Zealand: Fresh off the Boat. Aldershot: Avebury.

Mauss, Marcel. 1990. The Gift: The Form and Reason for Exchange in Archaic Societies. New York: W.W. Norton. Original edition, Essai sur le don, first published 1950 by Presses Universitaires de France en Sociologie et Anthropologie.

Miller, David (ed.). 1998. Material Cultures: Why Some Things Matter. Chicago: University of Chicago Press.

Ministry of Finance and Economic Management. 2017. Census 2011. Government of the Cook Islands. Online: www.mfem.gov.ck/statistics/ census-and-surveys/census/143-census-2011 (accessed 31 July 2017).

Myerhoff, Barbara. 1982. 'Rites of Passage: Process and Paradox'. In Celebration: Studies in Festivity and Ritual, ed. Victor Witter Turner, pp. 109-135. Washington: Smithsonian Institution Press.

Rasmussen, Wilkie Olaf Patua. 1995. 'The Sociopolitical Implications of Teina/Tuakana (Junior/Senior) Kinship Relationships among Tongareva People in South Auckland'. MA thesis. University of Auckland.

Sissons, Jeff. 2007. 'From Post to Pillar: God-houses and Social Fields in Nineteenth-century Rarotonga'. Journal of Material Culture 12(1): 47-63. DOI: 10.1177/1359183507074561.

—. 2008. Three Iconoclastic Episodes: Rematerializing Eastern Polynesia'. Conference paper given at the Joint Conference of the ASA, ASAANZ and AAS, Ownership and Appropriation, Auckland, 8-12 December.

Statistics New Zealand. 2008. Cook Island Maori People in New Zealand. Online: www.stats.govt.nz/Census/about-2006-census/pacific-profiles -2006/cook-island-maori-people-in-new-zealand.aspx/Cook-IslandMaori-profile-updated-May2008-1.pdf (accessed 21 January 2011).

- 2013. Census QuickStats about Culture and Identity/Pacific Peoples Ethnic Group. Online: www.stats.govt.nz/Census/2013-census/profileand-summary-reports/quickstats-culture-identity/pacific-peoples.aspx (accessed 17 May 2014). 
Thomas, Nicholas. 2000. 'Technologies of Conversion: Cloth and Christianity in Polynesia'. In Hybridity and Its Discontents: Politics, Science, Culture, ed. Avtar Brah and Annie E. Coombes, pp. 198-215. Florence, KY: Routledge.

Turner, Terence. 2006a. 'The "Transformation Problem" in Relation to the General Applicability of Maxian Value Theory'. Unpublished manuscript.

__ . 2006b. 'Kayapo Values: An Application of Marxian Value Theory to a Non-commodity Based System of Production'. Unpublished manuscript.

- 2008. 'Marxian Value Theory: An Anthropological Perspective'. Anthropological Theory 8(1): 43-56. DOI: $10.1177 /$ 1463499607087494.

—_. 2012. 'The Social Skin'. Hau: Journal of Ethnographic Theory 3(2): 219-243. Online: www.haujournal.org/index.php/hau/article/ view/236 (accessed 18 January 2014).

Turner, Victor Witter (ed.). 1982. Celebration: Studies in Festivity and Ritual. Washington: Smithsonian Institution Press.

Weber, Max. 2009. The Protestant Ethic and the Spirit of Capitalism, ed. Richard Swedberg. New York: W.W. Norton and Company Inc.

Weiner, Annette. 1976. Women of Value, Men of Renown: New Perspectives in Trobriand Exchange. Austin: University of Texas Press. 
This text is taken from Sinuous Objects: Revaluing Women's Wealth in the Contemporary Pacific, edited by Anna-Karina Hermkens and Katherine Lepani, published 2017 by ANU Press, The Australian National University, Canberra, Australia. 